\title{
MERDEKA BELAJAR DAN PENDIDIKAN KRITIS PAULO FRIERE DALAM PEMBELAJARAN PENDIDIKAN AGAMA ISLAM
}

\author{
Ifa Afida \\ Eka Diana \\ Dhevin M.Q Agus Puspita \\ IAI Al-Falah As-sunniyyah Kencong \\ ifa.87.aza@gmail.com
}

\begin{abstract}
The focus of this study is how the concept of independent learning which is a policy in education in Indonesia is currently associated with Paulo Friere's critical education and its implementation in learning Islamic Religious Education. For Paulo Friere, independent learning is a teaching process that frees students from all kinds of colonialism, such as the banking system. Freire's construction of education leads to education which will lead people out of the shackles of oppression. In line with that, the Merdeka Learning Program according to the Minister of Education and Culture will be the direction of future learning that focuses on improving the quality of human resources. Merdeka Learning is the beginning of the idea of improving the monotonous national education system. Overall, the humanistic values promoted by the Minister of Education and Culture's policies and the educational concepts offered by Friere are very relevant to be applied in education in Indonesia, especially Islamic Religious Education through the elements of educators, students and educational goals.
\end{abstract}

Keywords: freedom of learning, education of Paulo Friere, Islamic education

\begin{abstract}
Abstrak
Fokus kajian ini adalah bagaimana konsep merdeka belajar yang menjadi kebijakan pada pendidikan di Indonesia saat ini dikaitkan dengan pendidikan kritis Paulo Friere dan implementasinya dalam pembelajaran Pendidikan Agama Islam. Bagi Paulo Friere, merdeka belajar adalah proses pengajaran yang membebaskan peserta didik dari segala macam penjajahan, seperti banking system. Konstruksi pendidikan Freire mengarah kepada pendidikan yang nantinya menghantar orang keluar dari belenggu penindasan. Selaras dengan itu, Program Merdeka Belajar menurut Mendikbud akan menjadi arah pembelajaran ke depan yang fokus pada meningkatkan kualitas sumber daya manusia, Merdeka Belajar merupakan permulaan dari gagasan untuk memperbaiki sistem pendidikan nasional yang terkesan monoton. Secara menyeluruh, nilai humanis yang diusung oleh kebijakan mendikbud dan konsep pendidikan yang ditawarkan Friere sangat relevan untuk diaplikasikan dalam pendidikan di Indonesia, khususnya Pendidikan Agama Islam melalui unsur pendidik, peserta didik dan tujuan pendidikan.
\end{abstract}

Kata Kunci: merdeka belajar, pendidikan Paulo Friere, Pendidikan Agama Islam

\section{PENDAHULUAN}

Menteri Pendidikan Indonesia dalam kabinet Joko widodo periode dua cukup memberikan shock terapi bagi Netizen. Warga Medsos khususnya kalangan pemerhati dan praktisi pendidikan dipaksa melirik dengan ide-idenya. Istilah "Merdeka Belajar" dapat dikatakan muncul dari pidato Kemendikbud dalam rangka memperingati hari guru nasional, sebagaimana yang tertulis dibawah ini:

"Guru Indonesia yang tercinta, tugas Anda adalah yang termulia sekaligus yang tersulit. Anda ditugasi untuk membentuk masa depan bangsa, tetapi lebih sering diberi aturan dibandingkan 
Ifa Afida

Eka Diana

Dhevin M.Q Agus Puspita

dengan pertolongan. Anda ingin membantu murid yang mengalami ketertinggalan di kelas, tetapi waktu Anda habis untuk mengerjakan tugas administratif tanpa manfaat yang jelas. Anda tahu betul bahwa potensi anak tidak dapat diukur dari hasil ujian, tetapi terpaksa mengejar angka karena didesak berbagai pemangku kepentingan. Anda ingin mengajak murid keluar kelas untuk belajar dari dunia sekitarnya, tetapi kurikulum yang begitu padat menutup pintu petualangan.

Anda frustasi karena Anda tahu bahwa di dunia nyata kemampuan berkarya dan berkolaborasi akan menentukan kesuksesan anak, bukan kemampuan menghafal. Anda tahu bahwa setiap anak memiliki kebutuhan berbeda, tetapi keseragaman telah mengalahkan keberagaman sebagai prinsip dasar birokrasi. Anda ingin setiap murid terinspirasi, tetapi Anda tidak diberi kepercayaan untuk berinovasi. Saya tidak akan membuat janji-janji kosong kepada Anda. Perubahan adalah hal yang sulit dan penuh dengan ketidaknyamanan. Satu hal yang pasti, saya akan berjuang untuk kemerdekaan belajar di Indonesia. Namun, perubahan tidak dapat dimulai dari atas. Semuanya berawal dan berakhir dari guru. Jangan menunggu aba-aba, jangan menunggu perintah. Ambil langkah pertama." 1

Setelah membaca pidato tersebut, hal yang pertama muncul dibenak penulis adalah pendidikan kritis Paulo Friere, penulis melihat keduanya memiliki kesamaan dalam tujuannya yakni humanisasi. Paulo Friere dikenal sebagai tokoh humanis yang getol di masanya dengan salah satu karyanya berjudul "Pendidikan yang membebaskan". Sedangkan mendikbud dengan program "merdeka belajar"nya didorong oleh keinginannya menciptakan suasana belajar bahagia tanpa beban.

Pemerintah Indonesia sebenarnya selalu memberikan perhatian lebih terhadap sektor pendidikan. Ini dibuktikan dengan telah ditetapkan beberapa kebijakan pemerintah di sektor pendidikan, mulai dari program wajib belajar, beasiswa kepada masyarakat kurang mampu dan program-program yang mengupayakan peningkatan kualitas pendidikan, serta menganggarkan 20 persen APBN untuk sektor pendidikan. Selanjutnya, sambutan pidato Mendikbud pada Hari Guru Nasional (HGN) diatas, diasumsikan tidak lagi menjadi sebuah gagasan melainkan lebih pada sebuah kebijakan yang akan dilaksanakan. Faktanya selang beberapa minggu kemudian setelah perayaan HGN, langsung digulirkan kebijakan "Merdeka Belajar," sehingga ini membuktikan adanya korelasi antara "berjuang untuk kemerdekaan belajar di Indonesia" dengan "Merdeka Belajar".

Pendidikan secara umum dimaknai sebagai suatu proses untuk menemukan transformasi atau perubahan baik individual maupun communal. Dengan demikian, proses pendidikan pada hakekatnya adalah membebaskan diri seseorang dari segala jenis kungkungan, intimidasi, dan eksploitasi. Disinilah letak afinitas pendidikan, yaitu untuk membebaskan manusia secara komprehensif dari berbagai ikatan eksternal yang mengikat kebebasannya. ${ }^{2}$

\footnotetext{
${ }^{1}$ https://www.kemdikbud.go.id/main/blog/2019/11/pidato-mendikbud-nadiem-makarim-pada-upacara-benderaperingatan-hari-guru-nasional-2019

${ }^{2}$ Marianus Saesfao, 2020. Perbandingan Pemikiran Pendidikan Paulo Friere dengan Ajaran Taman Siswa dalam Implementasi Merdeka Belajar. Yogyakarya
} 
Berbicara pendidikan skala nasional, tentu merujuk apa yang tercantum dalam undang-undang sistem pendidikan nasional (UU Sisdiknas) nomor 20 tahun 2003 "berkembangnya potensi peserta didik agar menjadi manusia yang beriman dan bertakwa kepada Tuhan Yang Maha Esa, berakhlak mulia, sehat, berilmu, cakap, kreatif, mandiri, dan menjadi warga negara yang demokratis serta bertanggung jawab". Berdasarkan wacana tersebut, artikel ini membahas merdeka belajar perspektif pendidikan Paulo Friere dan implementasinya dalam pembelajasran PAI. Kajian ini tentu untuk kekayaan berpikir, menawarkan sebuah wacana dan paling penting sebagai counter konsepsi anomalis tentang pendidikan itu sendiri.

\section{KONSEP MERDEKA BELAJAR}

\section{KONSEP MERDEKA BELAJAR MENDIKBUD}

Pada akhir tahun 2019 yang lalu, menteri pendidikan dan kebudayaan terpilih, Nadiem Makarim, mencetuskan kebijakan baru dalam dunia pendidikan yang disebutnya dengan kebijakan merdeka belajar. Kebijakan ini dibuat bukan tanpa alasan. Dilatatarbelakangi hasil penelitian Programme for International Student Assesment (PISA) pada tahun 2019 menunjukkan bahwa hasil penilaian pada peserta didik Indonesia hanya menduduki posisi keenam dari bawah. Adapun untuk bidang matematika dan literasi, Indonesia menduduki posisi ke-74 dari 79 Negara. Beranjak dari fakta inilah gebrakan ini dicetuskan oleh Nadiem. ${ }^{3}$

Menteri Pendidikan dan Kebudayaan (Mendikbud) Nadiem Makarim menjelaskan alasan memilih konsep "Merdeka Belajar" sebagai program Kementerian Pendidikan dan Kebudayaan (Kemendikbud). Menurut Nadiem kata "Merdeka Belajar" paling tepat digunakan sebagai filosofi perubahan dari metode pembelajaran yang terjadi selama ini. Sebab, dalam "Merdeka Belajar" terdapat kemandirian dan kemerdekaan bagi lingkungan pendidikan menentukan sendiri cara terbaik dalam proses pembelajaran. ${ }^{4}$

Pentingnya memiliki SDM unggul merupakan solusi dalam menyelesaikan permasalahan bangsa, sebagaimana disampaikan oleh Mendikbud, bahwa: “Apapun kompleksitas masa depan, kalau SDM kita bisa menangani kompleksitas maka itu tidak menjadi masalah".Tentu SDM yang dikehendaki merupakan kapital intelektual yang memiliki keunggulan kompetitif dan komperatif, serta siap menghadapi era globalisasi. Apalagi saat ini bangsa Indonesia dihadapkan pada tantangan eksternal berupa hadirnya Revolusi industri 4.0 yang bertumpu pada cyber-physical system, dengan didukung oleh

\footnotetext{
${ }^{3}$ Mustaghfiroh, S. 2020. Konsep "Merdeka Belajar” Perspektif Aliran Progresivisme John Dewey. Jurnal Studi Guru Dan Pembelajaran, 3 (1 SE-Articles), 141-147. https://e-journal.my.id/jsgp/article/view/248

${ }^{4}$ https://nasional.kompas.com/read/2020/08/27/16515301/ini-penjelasan-mendikbud-nadiem-soal-konsep-merdekabelajar.
} 
Ifa Afida

Eka Diana

Dhevin M.Q Agus Puspita

kemajuan teknologi, basis informasi, pengetahuan, inovasi, dan jejaring, yang menandai era penegasan munculnya abad kreatif. Tantangan lainnya yang bersifat internal, berupa gejala melemahnya mentalitas anak-anak bangsa sebagai dampak maraknya simpul informasi dari media sosial. Menghadapi tantangan itu semua tentu harus diimbangi dengan pendidikan yang bermutu supaya dapat menjamin tumbuh kembangnya SDM yang berkualitas, yang bisa bertindak cepat, tepat, dan mampu beradaptasi dengan baik dalam mengantisipasi sekaligus mengatasi dampak negatif dari gelombang perubahan besar tersebut. $^{5}$

Kebijakan tentang "merdeka belajar" ini dijelaskan oleh Kemdikbud pada tanggal 11 Desember 2019 pada edarannya yang berisi penjelasan mengenai empat pokok kebijakan merdeka belajar ini, yaitu:

1. Ujian Sekolah Berstandar Nasional (USBN), pelaksanaannya digantikan dengan penilaian (asesmen) yang kebijakan pelaksanaannya diserahkan kepada pihak sekolah. Asesmen ini diselenggrakan untuk menilai kemampuan/kompetensi siswa dalam bentuk tes tertulis maupun bentuk penilaian lainnya yang bersifat lebih komprehensif, seperti penugasan atau penilaian portofolio.

2. Ujian Nasional (UN), ditiadakan. Peran UN kemudian digantikan dengan Asesmen Kompetensi Minimum dan Survei karakter. Penilaiannya meliputi aspek literasi, numerasi, dan survei karakter. Literasi disini tidak terbatas pada kemampuan membaca, namun secara luas yaitu kemampuan bernalar/memahami bacaan dan menggunakan bahasa. Adapun literasi, yaitu menilai kemampuan siswa dalam memahami dan menggunakan konsep matematika dalam kehidupan sehari-hari. Sementara survei karakter untuk mengetahui penerapan siswa terhadap nilai-nilai seorang individu pembelajar, nilai gotong royong, kebhinnekaan dan pancasila.

3. Penyederhanaan format Rencana Pelaksanaan Pembelajaran (RPP). Dalam hal ini guru diharapkan dapat secara lebih bebas memilih, membuat, serta menggunakan dan mengembangkan format RPP ini. Jika pada Kurikulum 2013 terdapat banyak komponen RPP hingga dapat mencapai 20 lembar, maka di RPP merdeka belajar ini, RPP cukup memuat 3 komponen inti yaitu tujuan, kegiatan pembelajaran, dan penilaian. Sementara komponen lain dapat dipilih secara mandiri. Penyederhanaan ini bertujuan agar guru memiliki lebih banyak waktu sehingga dapat mempersiapkan dan mengevaluasi proses pembelajaran itu sendiri.

4. Sistem zonasi Penerimaan Peserta Didik Baru (PPDB) lebih fleksibel. Dalam kebijakan ini, Kemendikbud memberikan fleksibilitas kepada daerah untuk mengakomodir ketimpangan

\footnotetext{
${ }^{5}$ https://gtk.kemdikbud.go.id/read-news/merdeka-belajar
} 
akses dan kualitas pendidikan di berbagai daerah dengan pembagian sistem zonasi yaitu $50 \%$ jalur zonasi, $15 \%$ jalur afirmasi, 5\% jalur perpindahan, sisanya jalur prestasi yang disesuaikan dengan kondisi daerah. Dalam hal ini daerah berwenang melakukan proporsi final dan menetapkan wilayah zonasi. ${ }^{6}$

Bila dicermati dari isi pokok kebijakan merdeka belajar jelas lebih difokuskan pada jenjang pendidikan dasar dan menengah, meskipun pada perkembangan selanjutnya berdimensi juga ke jenjang pendidikan tinggi (Dikti) melalui program "Kampus Merdeka".

\section{KONSEP PENDIDIKAN KRITIS PAULO FRIERE}

Pemikiran pendidikan menurut Paulo Freire berasal dari kondisi ketertindasan di Brazil pada masanya. Dalam kondisi itu, muncullah suatu kebudayaan yang dinamakan Freire "kebudayaan bisu" yang dilakukan oleh kaum penguasa untuk membodohkan rakyat dan sebagai sarana penindasan. Melihat kondisi ini, Freire bangkit dengan pemikirannya bahwa pendidikan harus memerdekakan manusia, bukan menindas.

Pendidikan liberal menurut Freire adalah pendidikan yang dapat membentuk setiap individu agar mampu mengatasi kondisi sosialnya menjadi lebih baik. Pendidikan juga bukan hanya sarana mentransfer pengetahuan melainkan harus diarahkan pada bagaimana individu tersebut dapat menjelaskan pengetahuan yang diperolehnya agar dapat digunakan di dalam kehidupan nyata. Pendidikan sejatinya memberikan kesempatan kepada peserta didik untuk mengetahui dan memahami tentang apa yang telah diperoleh dari pelajaran. ${ }^{7}$ Sehingga di dalam suasana belajar, sebaiknya pendidikan menciptakan suasana dialogis sehingga memberikan kebebasan kepada peserta didik yang nantinya akan menghasilkan individu yang kreatif.

Secara singkat dapat dikatakan bahwa Paulo Freire adalah seorang tokoh dalam praktisi pendidikan, yang menekankan pada pentingnya kesadaran dan penyadaran dalam pendidikan untuk membentuk manusia sejati seutuhnya. Kesadaran bukanlah sekedar alat, akan tetapi juga sebagai tujuan pendidikan itu sendiri. Kesadaran untuk melihat dunia sebagai perantara; karena manusia adalah makhluk yang sadar akan ketidaksempurnaannya dan sekaligus usaha untuk menjadi lebih manusiawi. ${ }^{8}$

\footnotetext{
${ }^{6}$ Pendidikan, M. 2019. Merdeka Belajar. Kementerian Pendidikan Dan Kebudayaan, 1- 21

${ }^{7}$ Freire, P. 2008. Pendidikan Kaum Tertindas,( Jakarta: LP3ES).

${ }^{8}$ Paulo Freire, 1972.Pedagogy Of The Oppressed, Terjemahan Myra Bergman Ramos, (Great Britain: Sheed and Ward).57
} 
Ifa Afida

Eka Diana

Dhevin M.Q Agus Puspita

Sebagai respon atas praktek pendidikan anti realitas, Freire menegaskan bahwa pendidikan harus diarahkan pada proses hadap-masalah. Titik tolak penyusunan progam pendidikan atau politik harus beranjak dari kekinian, eksistensial dan konkrit yang mencerminkan aspirasi-aspirasi rakyat. ${ }^{9}$

Paulo Freire mengembangkan pemahamannya tentang pendidikan dari pandangan mendasarnya yang banyak dikritik orang, yaitu bahwa dunia hanya terbagi atas 2 kelompok; kelompok penindas (oppressor) dan kelompok tertindas (oppressed). Setiap orang pastilah menjadi bagian dari salah satu kelompok. Dalam kerangka pemahaman ini, praktik belajar mengajar yang banyak terjadi sebelumnya dapat dipandang sebagai pendidikan yang menindas karena hanya melakukan proses "satu arah" dari guru dan murid. Paradigma yang mengandalkan hafalan ini berwatak pasif, tidak menyulut keberanian, penalaran dan kreativitas, padahal nalar dan kreativitas inilah yang dibutuhkan oleh manusia sejati. ${ }^{10}$

Freire menggaris bawahi bahwa dalam pendidikan terdapat tiga unsur fundamental yakni pengajar, peserta didik dan realitas. Hubungan antar unsur pertama dengan unsur kedua seperti halnya teman yang saling melengkapi dalam proses pembelajaran. Keduanya tidak berfungsi secara struktural formal dan nantinya akan memisahkan keduanya. ${ }^{11}$

Ada hal lain juga yang mempengaruhi bagaimana kita dapat mengetahui realitas, yaitu saat keadaan kesadaran tertindas menimbulkan masalah epistemologis yang bersifat historis. Karena bagaimana manusia mengetahui tergantung pada bagaimana ia mengalami kenyataan melalui pikiranbahasa. Refleksi atas realitas menemukan suatu situasi historis, dimana sejumlah manusia melanggengkan hak-hak istimewa pribadi dengan membiarkan orang lain dalam situasi tertindas. Saat orang lain menjadi yang tertindas karena penindas, saat itu pula penindas merasakan dunia seakan hanya ada aku (penindas) dan dia (tertindas), ini akan merusak mempengaruhi bagaimana realitas diketahui.

Saat manusia muncul dari dualitas kesadaran yang tertindas, kesadarannya berkembang dari kesadaran 'magis' menuju kesadaran 'kritis'. Kesadaran penindas dan yang tertindas yang dibicarakan freire menunjukan dua keadaan keterasingan yang berlebihan dalam kontradiksi penindas-tertindas. Namun keduanya sama sekali tidak melemahkan keadaan kesadaran yang dibicarakan oleh Freire. Saat manusia bergerak dari keadaan keterasingan menuju humanisasi, ia tidak maju seketika, tetapi secara bertahap. Arena kesadaran manusia dikondisikan oleh realitas sebagaimana dialami dan dihantarkan lewat pikiran-bahasa. Saat manusia mengerti semua hubungan kausal suatu situasi, termasuk kekuatannya sendiriuntuk berefleksi dan ikut campur dalam sejarah, Freire menyatakan bahwa mereka

\footnotetext{
${ }^{9}$ Abuddin Nata, 2003.Pemikiran Para Tokoh Pendidikan Islam, Cet.III, (Jakarta: Rajawali Press), 56-57

${ }^{10}$ A.B.Susanto, Pendidikan Penyadaran Paulo Friere Jurnal At- Ta'dib Vol. 4 no 1 dalam ejournal.unida.gontor.ac..id

${ }^{11}$ Ibid. 89
} 
'sepenuhnya terarah' pada semesta, karena dengan cara ini dia menemukan apa yang sebelumnya sudah implisit tetapi tidak menarik perhatian dalam fenomena yang ia terima. ${ }^{12}$

\section{KONSEP PEMBELAJARAN PENDIDIKAN AGAMA ISLAM}

\section{Pengertian Pembelajaran PAI}

Pembelajaran menurut Oemar Hamalik mendefinisikan pembelajaran sebagai suatu kombinasi yang tersusun, meliputi unsur-unsur manusiawi, fasilitas, perlengkapan dan prosedur yang saling mempengaruhi untuk mencapai tujuan pembelajaran. ${ }^{13}$

Pada hakekatnya pembelajaran terkait dengan bagaimana membelajarkan peserta didik atau bagaimana membuat peserta didik dapat belajar dengan mudah dan terdorong oleh kemampuannya sendiri untuk mempelajari apa yang teraktualisasikan dalam kurikulum sebagai kebutuhan peserta didik. $^{14}$

Adapun pengertian Pendidikan Agama Islam adalah usaha sadar yang dilakukan pendidik dalam rangka mempersiapkan peserta didik untuk menyakini, memahami dan mengamalkan ajaran Islam melalui kegiatan bimbingan, pengajaran atau pelatihan yang telah ditentukan untuk mencapai tujuan yang telah ditetapkan. ${ }^{15}$

Sebagai perwujudan manusia yang sanggup menghadapi tantangan, peluang dan kendala dalam memasuki kehidupan masa depan itu, pendidikan Islam memiliki peluang yang amat luas. Hal ini mudah dimengerti karena pendidikan Islam sebagaimana telah disebutkan di atas adalah pendidikan yang seimbang dalam mempersiapkan anak didik, yakni anak didik yang tidak hanya mampu mengembangkan kreativitas intelektual dan imajinasi secara mandiri, tetapi juga memiliki ketahanan mental spiritual serta mampu beradaptasi dan merespon problematika yang dihadapi sesuai kerangka dasar ajaran Islam. Atas dasar ini pula tidaklah mengherankan jika pada saat ini masyarakat lebih banyak menaruh minatnya untuk mendidik anak didiknya pada sekolah-sekolah yang memiliki keunggulan sesuai ajaran agama Islam. Para orang tua murid selain menginginkan anakanaknya menjadi orang yang berguna bagi dirinya, negara dan bangsanya, tetapi juga menjadi anak yang berakhlak baik dan berjiwa Islami. $^{16}$

\footnotetext{
${ }^{12}$ Paulo Freire, 2008. Pendidikan Kaum Tertindas, (Jakarta : Pustaka LP3ES). 70

${ }^{13}$ Oemar Hamalik. 1999. Kurikulum Dan Pembelajaran. (Jakarta: Bumi Aksara). 57

${ }^{14}$ Muhaimin. 2002. Peradigma Pendidikan Islam: Upaya Mengefektifkan PAI di Sekolah. (Bandung: Remaja Rosdakarya). 145

${ }^{15}$ Ibid. 183

${ }^{16}$ Rochidin Wahab, "Pembelajaran Pai dalam Mewarna Pendidikan di Sekolah" dalam Jurnal Kependidikan Vol. 41, Nomor 2, November 2011
} 
Ifa Afida

Eka Diana

Dhevin M.Q Agus Puspita

\section{Komponen dalam Pembelajaran PAI}

Komponen merupakan bagian dari suatu sistem yang meiliki peran dalam keseluruhan berlangsungnya suatu proses untuk mencapai tujuan sistem. Komponen pendidikan berarti bagianbagian dari sistem proses pendidikan, yang menentukan berhasil dan tidaknya atau ada dan tidaknya proses pendidikan. Bahkan dapat diaktan bahwa untuk berlangsungnya proses kerja pendidikan diperlukan keberadaan komponen-komponen tersebut. Komponen-komponen yang memungkinkan terjadinya proses pendidikan atau terlaksananya proses mendidik minimal terdiri dari 6 komponen, yaitu

a) Tujuan pendidikan

b) Peserta didik

c) Isi pendidikan

d) Konteks yang mempengaruhi suasana pendidikan. ${ }^{17}$

Suatu proses belajar mengajar dapat berjalan efektif apabila seluruh komponen yang berpengaruh dalam proses belajar mengajar saling mendukung dalam rangka mencapai tujuan pembelajaran sebagai suatu sistem, tentu saja kegiatan belajar mengajar khususnya Pendidikan Agama Islam mendukung sejumlah komponen dan berpengaruh terhadap proses pembelajaran Pendidikan Agama Islam, hal ini meliputi: tujuan, bahan pelajaran, kegiatan belajar mengajar, alat, metode, sumber belajar, evaluasi. ${ }^{18}$

a) Tujuan

Tujuan merupakan komponen yang berfungsi sebagai indikator keberhasilan pengajaran akan mewarnai corak anak didik bersikap dan berbuat dalam lingkungan sosialnya.

b) Bahan Pelajaran

Bahan pelajaran merupakan subtansi yang akan disampaikan dalam proses belajar mengajar atas dasar tujuan instrukisonal dan sebagai sumber belajar bagi anak didik, hal ini dapat berwujud benda, dan isi pendidikan yang berupa pengetahuan, prilaku, nilai, sikap dan metode perolehannya. ${ }^{19}$

c) Kegiatan Belajar Mengajar

Kegiatan belajar mengajar menentukan sejauh mana tujuan yang telah ditetapkan dapat dicapai. Dalam hal ini guru hanya sebagai fasilitator dan motivator, sehingga guru

\footnotetext{
${ }^{17} \mathrm{http} / / / \mathrm{blog} . u n n e s . a c . i d / s e p u t a r p e n d i d i k a n / 2015 / 10 / 13 /$ komponen-komponen-pendidikan/

18 Syiful bahri \& Aswan Zain. 2002. Strategi Belajar Mengajar. (Jakarta: Rineka Cipta). 45

${ }^{19}$ Ibid. 48
} 
harus dapat memahami dan memperhatikan aspek individual siswa/anak didik baik dalam biologis, intelektual dan psikologis.

d) Alat

Alat merupakan segala sesuatu cara yang dapat digunakan dalam rangka mencapai tujuan pengajaran memperjelas bahan pengajaran yang diberikan guru atau yang dipelajari siswa.

e) Metode

Metode merupakan cara yang digunakan untuk mencapai tujuan yang telah ditetapkan dalm proses belajar mengajar. Kombinasi dalam penggunaan dari berbagai metode pengajaran merupakan keharusan dalam praktek mengajar.

f) Sumber Belajar

Sumber belajar merupakan bahan atau materi untuk menambah ilmu pengetahuan yang mengandung hal-hal bagi si pelajar. ${ }^{20}$

g) Evaluasi

Evaluasi merupakan proses menentukan suatu obyek tertentu berdasarkan kriteria tertentu. Dalam pembelajaran berfungsi untuk mengetahui tercapai tidaknya tujuan pembelajaran instruksional dan sebagai bahan dalam memperbaiki proses belajar Pendidikan Agama Islam.

Ketujuh komponen tersebut saling berhubungan satu sama lain, tidak ada satu komponen yang dapat dilepaskan satu sama lainnya karena dapat mengakibatkan tersedatnya proses belajar Pendidikan Agama Islam.

\section{IMPLEMENTASI PROGRAM MERDEKA BELAJAR DAN PENDIDIKAN KRITIS PAULO FRIERE DALAM PEMBELAJARAN PAI}

Supaya lebih memahami konsep merdeka belajar sebagaimana telah dikupas tuntas di atas, ada baiknya konsep Merdeka Belajar juga dikaji secara teoritis berdasarkan terminologi arti kata "Merdeka" dan konsep "Belajar" itu sendiri. Menurut Kamus Besar Bahasa Indonesia (KBBI), kata Merdeka memiliki tiga pengertian: (1) bebas (dari perhambatan, penjajahan dan sebagainya), berdiri sendiri; (2) tidak terkena atau lepas dari tuntutan; (3) tidak terikat, tidak oleh tergantung kepada orang atau pihak tertentu. Adapun konsep "Belajar" menurut Sagala (2006), dapat dipahami sebagai usaha atau berlatih supaya mendapatkan suatu kepandaian. Ditambahkan pula menurut Sudjana (2013), belajar bukan semata kegiatan menghafal dan bukan mengingat.

\footnotetext{
${ }^{20}$ Damiyati \& Mudjiono. 1999.Belajar Dan Pembelajaran. (Jakarta: Rineka Cipta), h. 33-34
} 
Ifa Afida

Eka Diana

Dhevin M.Q Agus Puspita

Belajar adalah; (1) suatu proses yang ditandai dengan adanya perubahan pada diri seseorang, dapat ditunjukkan seperti berubah pengetahuannya, pemahamannya, sikap dan tingkah lakunya, keterampilannya, kecakapan, dan kemampuannya, daya reaksinya, daya penerimaannya dan lain-lain aspek yang ada ada individu; (2) belajar adalah proses aktif, proses berbuat melalui berbagai pengalaman; (3) belajar adalah proses mereaksi terhadap semua situasi yang ada di sekitar individu; (4) Belajar adalah proses yang diarahkan kepada tujuan; dan (5) Belajar adalah proses melihat, mengamati, memahami sesuatu. Jadi apabila kita berbicara tentang belajar, maka prinsipnya berbicara bagaimana mengubah tingkah laku seseorang. Pastinya program "Merdeka Belajar" bukanlah sebuah kebijakan yang secara tiba-tiba muncul, melainkan melalui serangkaian proses yang panjang dan matang, setelah beberapa waktu lalu pasca dilantik menjadi Mendikbud banyak melakukan kajian komprehensif dengan mengundang dan mendatangi para pakar pendidikan, pengawas, kepala sekolah, guru-guru, organisasi profesi guru dan lain sebagainya, untuk mendengar berbagai masukan terkait permasalahan praktik pendidikan. Lebih jelasnya lagi keempat prinsip merdeka belajar tersebut diuraian sebagai berikut.

Pertama; USBN 2020. Berdasarkan Permendikbud Nomor 43 Tahun 2019, tentang Penyelenggaraan Ujian yang Diselengarakan Satuan Pendidikan dan Ujian Nasional, khususnya pada Pasal 2, ayat 1; menyatakan bahwa ujian yang diselenggarakan oleh satuan pendidikan merupakan penilaian hasil belajar oleh satuan pendidikan yang bertujuan untuk menilai pencapaian standar kompetensi lulusan untuk semua mata pelajaran. Selanjutnya dijelaskan pada Pasal 5, ayat 1, bahwa; bentuk ujian yang diselenggarakan oleh Satuan Pendidikan berupa portofolio, penugasan, tes tertulis, atau bentuk kegiatan lain yang ditetapkan Satuan Pendidikan sesuai dengan kompetensi yang diukur berdasarkan Standar Nasional Pendidikan. Ditambahkan pula pada penjelasan Pasal 6, ayat 2, bahwa; untuk kelulusan peserta didik ditetapkan oleh satuan pendidikan/program pendidikan yang bersangkungan. Dengan demikian jika melihat isi Permendikbud tersebut menunjukkan, bahwa Guru dan sekolah lebih merdeka untuk menilai hasil belajar siswa.

Kedua; UN adalah kegiatan pengukuran capaian kompetensi lulusan pada mata pelajaran tertentu secara nasional dengan mengacu pada standar kompetensi lulusan. Merupakan penilaian hasil belajar oleh pemerintah pusat yang bertujuan untuk menilai pencapaian kompetensi lulusan secara nasional pada mata pelajaran tertentu (Permendikbud No. 43 Tahun 2019). Terkait untuk pelaksanaan UN tahun 2020, sebagaimana disampaikan Mendikbud merupakan kegiatan UN yang terakhir kalinya, selanjutnya ditahun 2021 mendatang UN akan digantikan dengan istilah lain yaitu Asesmen Kompetensi Minimun dan Survey Karakter. Asesmen dimaksudkan untuk mengukur kemampuan peserta didik untuk bernalar menggunakan bahasa dan literasi, kemampuan bernalar menggunakan matematika atau numerasi, dan penguatan pendidikan karakter. Adapun untuk teknis pelaksanaan ujian 
tersebut akan dilakukan ditengah jenjang sekolah. Misalnya di kelas 4, 8, 11, dengan maksud dapat mendorong guru dan sekolah untuk memetakan kondisi pembelajaran, serta mengevaluasi sehingga dapat memperbiki mutu pembelajaran. Dengan kata lain, agar bisa diperbaiki kalau ada hal yang belum tercapai. Sebagai catatan hasil ujian ini tidak digunakan sebagai tolok ukur seleksi siswa kejenjang berikutnya. Adapun untuk standarisasi ujian, arah kebijakan ini telah mengacu pada level internasional, mengikuti tolok ukur penilain yang termuat dalam Programme for International Student Assessment (PISA) dan Trends in International Mathematics and Science Study (TIMSS), tetapi penuh dengan kearifan lokal (Media Indonesia, 12/12/2019). Untuk kompetensi PISA lebih difokuskan pada penilaian kemampuan membaca, matematika, dan sains, yang diberlakukan pada negara-negara yang tergabung dalam Organization for Economic Cooperation and Development(OECD), sedangkan untuk kompetensi TIMSS lebih menekankan pada penilaian kemampuan matematika, dan sains, sebagai indikator kualitas pendidikan, yang tergabung dalam wadah International Association for the Evaluation of Educational Achievement, berpusat di Boston, Amerika Serikat (Koran Tempo, 12/12/2019).

Terkait Asesmen Kompetensi Minimum dan Survei Karakter, dimaksudkan supaya setiap sekolah bisa menentukan model pembelajaran yang lebih cocok untuk murid-murid, daerah, dan kebutuhan pembelajaran mereka, serta Asesmen Kompetensi Minimum tidak sekaku UN, seperti yang disampaikan Dirjen GTK Supriano. ${ }^{21}$

Selanjutnya untuk aspek kognitif Asessmen Kompetensi Minimum, menurut Mendikbud materinya dibagi dalam dua bagian: (1) Literasi; bukan hanya kemampuan untuk membaca, tapi juga kemampuan menganalisa suatu bacaan, kemampuan memahami konsep di balik tulisan tersebut; (2) Numerasi; berupa kemampuan menganalisa, menggunakan angka-angka. Jadi ini bukan berdasarkan mata pelajaran lagi, bukan penguasaan konten, atau materi. Namun ini didasarkan kepada kompetensi dasar yang dibutuhkan murid-murid untuk bisa belajar, apapun mata pelajarannya (Media Indonesia, 12/12/2019).

Ketiga; Dalam hal RPP, berdasarkan Surat Edaran Mendikbud Nomor 14 Tahun 2019, tentang Penyederhanaan RPP, isinya meliputi: (1) penyusunan RPP dilakukan dengan prinsip efisien, efektif, dan berorientasi pada siswa; (2) Dari 13 komponen RPP yang tertuang dalam Permendikbud Nomor 22 Tahun 2016, yang menjadi komponen inti adalah tujuan pembelajaran, langkah-langkah pembelajaran, dan penilaian pembelajaran (assesment) yang wajib dilaksanakan oleh guru, sedangkan sisanya hanya sebagai pelengkap; dan (3) Sekolah, Kelompok Guru Mata Pelajaran dalam sekolah, Kelompok Kerja Guru/Musyawarah Guru Mata Pelajaran (KKG/MGMP) dan individu guru secara bebas dapat memilih, membuat, menggunakan, dan mengembangkan format RPP secara mandiri untuk sebesar-

${ }^{21}$ https://www.alinea.id/nasional/merdeka-belajar

55 | Falasifa, Vol. 12 Nomor 2 September 2021 
Ifa Afida

Eka Diana

Dhevin M.Q Agus Puspita

besarnya keberhasilan belajar siswa. Adapun RPP yang telah dibuat dapat digunakan dan dapat disesuaikan dengan ketentuan sebagaaimana maksud pada angka 1, 2, dan 3.

Bila dicermati dari keseluruhan isi surat edaran mendikbud tersebut, dapat dimaknai bahwa penyusunannya lebih disederhanakan dengan memangkas beberapa komponen. Guru diberikan keleluasaan dalam proses pembelajaran untuk memilih, membuat, menggunakan, dan mengembangkan format RPP, sebab gurulah yang mengetahui kebutuhan siswa didiknya dan kebutuhan khusus yang diperlukan oleh siswa di daerahnya, karena karakter dan kebutuhan siswa di masing-masing daerah bisa berbeda. Untuk penulisan RPP-nya supaya lebih efisiensi dan efektif, cukup dibuat ringkas bisa dalam satu halaman, sehingga guru tidak terbebani oleh masalah administrasi yang rijit. Diharapkan melalui kebebasan menyusun RPP kepada guru, siswa akan lebih banyak berinteraksi secara aktif, dinamis, dengan model pembelajaran yang tidak kaku.

Keempat; Untuk PPDB, berdasarkan Permendikbud baru Nomor 44 Tahun 2019 tentang PPDB 2020, sebagaimana dinyatakan pada Pasal 11, dalam persentase pembagiannya meliputi: (1) untuk jalur zonasi paling sedikit 50 persen; (2) jalur afirmasi paling sedikit 15 persen; (3) jalur perpindahan tugas orang tua/wali lima persen; dan (4) jalur prestasi (sisa kuota dari pelaksanaan jalur zonasi, afirmasi dan perpindahan orang tua / wali (0-30 persen). Jelas ini berbeda dengan kebijakan PPDB pada tahuntahun sebelumnya, setidaknya terdapat dua hal penting: (1) kuota penerimaan siswa baru lewat jalur berprestasi, semula 15 persen, sekarang menjadi 30 persen; dan (2) adanya satu penambahan baru jalur PPDB, yaitu melalui jalur afirmasi, yang ditujukan terutama bagi mereka yang memegang Kartu Indonesia Pintar (KIP). Dengan demikian untuk PPDB 2020 masih tetap menggunakan sistem zonasi, akan tetapi dalam pelaksanaannya lebih bersifat fleksibel, dengan maksud agar dapat mengakomodir ketimpangan akses dan kualitas di berbagai daerah. Terpenting dalam prorporsi finalisasinya, daerah berwenang untuk menentukan dan menetapkan wilayah zonasinya. Secara umum sistem zonasi dalam PPDB itu sudah baik, karena dapat mendorong hilangnya diskriminasi bagi anggota masyarakat untuk bersekolah di sekolah-sekolah terbaik.

Berdasarkan kajian teori tersebut diatas maka konsep Merdeka dan Belajar menurut hemat penulis dapat dipersepsikan sebagai upaya untuk menciptakan suatu lingkungan belajar yang bebas untuk berekspresi, bebas dari berbagai hambatan terutama tekanan psikologis. Bagi guru dengan memiliki kebebasan tersebut lebih fokus untuk memaksimalkan pada pembelajaran guna mencapai tujuan (goal oriented) pendidikan nasional, namun tetap dalam rambu kaidah kurikulum. Bagi siswa bebas untuk berekspresi selama menempuh proses pembelajaran di sekolah, namun tetap mengikuti kaidah aturan di sekolah. Siswa bisa lebih mandiri, bisa lebih banyak belajar untuk mendapatkan suatu kepandaian, dan hasil dari proses pembelajaran tersebut siswa berubah secara pengetahuan, 
pemahaman, sikap/karakter, tingkah laku, keterampilan, dan daya reaksinya, sejalan dengan apa yang diamanatkan dalam tujuan UU Sisdiknas Tahun 2003, yakni; untuk mengembangkan potensi peserta didik agar menjadi manusia yang beriman dan bertakwa kepada Tuhan Yang Maha Esa, berakhlak mulia, sehat, berilmu, cakap, kreatif mandiri, dan menjadi warga negara yang demokratis serta bertanggungjawab.

Sedangkan Pendidikan yang membebaskan menurut Paulo Freire di dalamnya harus bersifat Dialogis-Komunikatif. Guru adalah sosok manusia yang selayaknya dihormati dan dimuliakan dengan penghormatan dan pemuliaan yang setinggi-tingginya (sepantas dan sepatutnya) dari seorang murid, dan guru untuk mendapatkan hak-hak tersebut semaksimal mungkin berupaya menyeimbangkannya dengan selalu meningkatkan integritas, intelektualitas, kapabalitas, dan menjaga harga dirinya agar kebutuhan murid untuk belajar dengan berbagai ilmu pengetahuan dan keteladanan akhlak yang baik dapat terpenuhi dengan baik dan proporsional.

Dalam menjelaskan hubungan guru dan murid, Freire berpendapat pentingnya dialog dalam proses belajar mengajar karena dalam dialog itu mereka saling menghargai, saling belajar, saling menghindarkan dari tekanan penguasa. ${ }^{22}$ Dialog secara kritis perlu diadakan, sehingga masing-masing dihargai sebagai manusia. Dialog mengembangkan kedua belah pihak, baik guru maupun murid. Dalam dialog itu masing-masing bukan hanya mempertahankan identitas mereka, tetapi juga berkembang bersama. Dalam dialog juga hak asasi manusia dihargai dan tidak dimatikan demi kemenangan satu pihak.

Satu analisis yang cermat tentang hubungan guru dengan murid telah dikemukakan olehnya ketika ia mengemukakan kritik tajam atas konsep pendidikan gaya bank. Konsep gaya bank melahirkan adanya kontradiksi dalam hubungan guru dengan murid. Bahkan lebih dari itu konsep pendidikan gaya bank juga memelihara dan mempertajamnya sehingga mengakibatkan terjadinya kebekuan berfikir dan tidak munculnya kesadaran kritis pada diri murid.

Konsep pendidikan gaya bank merupakan suatu gejala, dimana guru berlaku sebagai penyimpan (depositor) yang memperlakukan murid-muridnya sebagai tempat penyimpanan-semacam bank-yang kosong dan karenanya perlu diisi. Dalam proses semacam ini murid tidak lebih sebagai gudang yang tidak kreatif sama sekali. Murid dianggap berada dalam kebodohan absolut. Ini merupakan suatu penindasan kesadaran manusia. Pendidikan karenanya menjadi sebuah kegiatan menabung dimana murid adalah celengannya dan guru adalah penabungnya. Dalam hal ini yang terjadi bukanlah proses komunikasi, tetapi guru menyampaikan pernyataan-pernyataan dan mengisi tabungan yang diterima,

\footnotetext{
${ }^{22}$ Suparno, P. 2001. "Relevansi dan Reorientasi Pendidikan di Indonesia”, Basis, No.01-02 Tahun ke 50 JanuariFebruari.
} 
Ifa Afida

Eka Diana

Dhevin M.Q Agus Puspita

dihafal, dan diulangi dengan patuh oleh murid. Ruang gerak yang disediakan untuk kegiatan murid hanya terbatas pada menerima, mencatat, dan menyimpan.

Konsep pendidikan gaya bank tidak mengenal pemecahan masalah kontradiksi guru dan murid, sebaliknya memelihara dan mempertajam kontradiksi itu melalui cara-cara dan kebiasaan yang mencerminkan suatu keadaan masyarakat tertindas (murid):

a) Guru mengajar, murid belajar;

b) Guru mengetahui segala sesuatu, murid tidak tahu apa-apa;

c) Guru berpikir, murid dipikirkan;

d) Guru bercerita, murid patuh mendengarkan cerita;

e) Guru menentukan peraturan, murid patuh diatur;

f) Guru memilih dan memaksakan pilihannya;

g) Guru berbuat, murid membayangkan dirinya berbuat melalui perbuatan gurunya;

h) Guru memilih bahan dan isi pelajaran, murid menyesuaikan diri dengan pelajaran itu;

i) Guru mencampuradukkan kewenangan ilmu pengetahuan dan kewenangan jabatannya, yang ia lakukan untuk menghalangi kebebasan murid;

j) Guru adalah subyek dalam proses belajar, murid hanyalah obyek belaka. ${ }^{23}$

Dari penjelasan di atas dapat dilihat bahwa guru yang menjadi pusat segalanya. Bagi murid, guru sebagai prototipe manusia ideal yang harus ditiru dan diteladani dalam semua hal. Konsep pendidikan ini sangat efektif membekukan kesadaran kritis dan mereduksi keterlibatan murid dalam proses belajar mengajar baik di dalam maupun di luar kelas, di samping itu mengurangi dan menghapuskan daya kreasi pada murid serta menumbuhkan sikap mudah percaya.

Konsep pembebasan Freire dalam kaitannya hubungan antara guru dan murid adalah berusaha melepaskan belenggu yang menjerat paradigma berfikir guru dan murid, untuk kemudian mereka dapat melepaskan keterkungkungan itu, lalu menjadi manusia yang mengerti akan arti kemanusiaannya. Freire menempatkan guru sebagai mitra murid dalam segi kemanusiaan dan demokrasi dan bahwa setiap murid pada dasarnya dapat berlaku aktif, mampu berbuat dan bertanggung jawab, serta mampu menjadi dirinya sendiri.

Konsep yang digunakan Freire sebagai ciri dari pendidikan yang membebaskan adalah: pertama, pendidikan sebagai proses transformasi budaya ${ }^{24}$ artinya dalam bertransformasi budaya, kegiatan pewarisan individu dialihkan dari satu generasi ke generasi yang lain. Dalam proses itu perlu ditanamkan

\footnotetext{
${ }^{23}$ Azzet, A. M. 2017. Pendidikan yang Membebaskan. Jogyakarta: Ar-Ruzz Media.

${ }^{24}$ Freire, P. 2008. Pendidikan Kaum Tertindas, ( Jakarta: LP3ES).
} 
nilai-nilai kejujuran dan tanggung jawab; kedua, membentuk pribadi manusia, artinya dalam pendidikan yang membebaskan berisikan laku-laku pemahaman, bukan pengalihan-pengalihan informasi. Pendidikan hendaknya dapat membentuk kepribadian manusia. Maka dalam proses pendidikan hendaknya terdapat hubungan dialogis antara pendidik dan peserta didik; ketiga, manusia berwarganegara. Hal yang perlu diperhatikan adalah bagaimana manusia memahami pendidikan sebagai suatu dasar yang dapat memperkokoh watak manusia. Dari dasar yang kokoh tentu akan menciptakan manusia yang bertaqwa, taat pada hukum dan pada Sang Khalik; keempat, bebas mengemukakan pendapat. Dalam pendidikan liberal diharapkan dapat memberi kebebasan kepada peserta didik untuk mengemukakan pendapatnya, dan tentu saja harus berlandaskan pemahaman yang cukup dalam berpendapat; kelima, ciri dialogis yang selalu berpandangan bahwa setiap orang memiliki potensi yang perlu dikembangkan dengan tujuan untuk berubah baik pribadi maupun lingkungannya.

Metode pendidikan yang digunakan oleh Freire dikenal dengan istilah "pendidikan hadap masalah" (Problem posing education). Metode ini digunakan sebagai ilmu antagonistis dari konsep pendidikan gaya bank dan berorientasi pada pembebasan manusia. Konsep "problem-posing” bertolak dari konsep manusia sebagai makhluk yang sadar dan kesadaran tersebut diarahkan kepada dunia. Masalah- masalah manusia yang berhubungan dengan dunia, dihadapkan untuk dipecahkan. Konsep ini menuntut pemecahan masalah kontradiksi antara guru dan murid. "Problem-posing” bertujuan untuk mewujudkan komunikasi ataupun dialog dan menolak pengetahuan yang dihasilkan dari pernyataanpernyataan. ${ }^{25}$ Bagi Freire pendidikan hadap masalah sifatnya membebaskan manusia karena berisi lakulaku pemahaman (hubungan dialogis), bukan pengalihan informasi. Murid diberi kesempatan untuk berdialog secara terbuka dan bebas, pendapatnya dihargai, ada jawaban masalah atas dasar pengalaman setiap murid dan setiap murid saling mendidik satu sama lain. ${ }^{26}$

\section{KESIMPULAN}

Merdeka belajar menurut konsepsi Menteri Pendidikan dan Paulo Friere memiliki relevansi dalam konteks pendidikan Indonesia kontemporer. Relevan dalam tingkat wacana maupun kenyataan secara kontekstual pendidikan di Indonesia hari ini. Walaupun Paulo Friere hidup pada masa 90an, namun wacana pendidikannya masih bisa menjawab problematika pendidikan hari ini. Pendidikan yang humanis dengan tujuan membebaskan setiap individu merupakan konsep pendidikan yang dikemukakan oleh Freire dan Menteri Pendidikan. Implikasi konsep pendidikan yang membebaskan oleh kedua tokoh ini dilihat sebagai pendidikan itu harus sampai pada titik kulminasi dimana ia mampu

\footnotetext{
${ }^{25}$ Supriyanto. 2013. "Paulo Freire: Biografi Sosial Intelektual Modernisme Pendidikan”, Jurnal Al-Ta'dib, Vol. 6, No. 2, Juli-Desember.

${ }^{26}$ Idris, M. 2009. "Pendidikan Pembebasan: Telaah Terhadap Pemikiran Paulo Freire". Researchgate.net. DOI: http://doi.org.10.21093/di.v9i2.282
} 
Ifa Afida

Eka Diana

Dhevin M.Q Agus Puspita

membawa manusia untuk merdeka lahir dan batin (totalitas manusia). Freire sangat menekankan unsur humanisme pendidikan dimana ia mengutuk banking education dan menawarkan metode dialogis dan conscientization. Metode dialogis dianggap sangat cocok digunakan dalam proses pendidikan.

\section{DAFTAR PUSTAKA}

Azzet, A. M. 2017. Pendidikan yang Membebaskan. Jogyakarta: Ar-Ruzz Media.

Bahri, Syiful \& Aswan Zain. 2002. Strategi Belajar Mengajar. (Jakarta: Rineka Cipta).

Damiyati \& Mudjiono. 1999.Belajar Dan Pembelajaran. (Jakarta: Rineka Cipta)

Freire, Paulo. 1972.Pedagogy Of The Oppressed, Terjemahan Myra Bergman Ramos, (Great Britain: Sheed and Ward)

Freire, Paulo 2008. Pendidikan Kaum Tertindas, (Jakarta : Pustaka LP3ES)

Hamalik, Oemar. 1999. Kurikulum Dan Pembelajaran. (Jakarta: Bumi Aksara)

Idris, M. 2009. "Pendidikan Pembebasan: Telaah Terbadap Pemikiran Paulo Freire”. Researchgate.net. DOI: http://doi.org.10.21093/di.v9i2.282

Marianus Saesfao, 2020. Perbandingan Pemikiran Pendidikan Paulo Friere dengan Ajaran Taman Siswa dalam Implementasi Merdeka Belajar. Yogyakarya

Mustaghfiroh, S. 2020. Konsep “Merdeka Belajar” Perspektif Aliran Progresivisme John Dewey. Jurnal Studi Guru Dan Pembelajaran, 3 (1 SE-Articles) https://e-journal.my.id/jsgp/article/view/248

Muhaimin. 2002. Peradigma Pendidikan Islam: Upaya Mengefektifkan PAI di Sekolah. (Bandung: Remaja Rosdakarya

Nata, Abuddin. 2003.Pemikiran Para Tokoh Pendidikan Islam, Cet.III, (Jakarta: Rajawali Press)

Pendidikan, M. 2019. Merdeka Belajar. Kementerian Pendidikan Dan Kebudayaan

Suparno, P. 2001. "Relevansi dan Reorientasi Pendidikan di Indonesia”, Basis, No.01-02 Tahun ke 50 JanuariFebruari.

Susanto, A.B. Pendidikan Penyadaran Paulo Friere Jurnal At- Ta'dib Vol. 4 no 1 dalam ejournal.unida.gontor.ac..id

Supriyanto. 2013. "Paulo Freire: Biografi Sosial Intelektual Modernisme Pendidikan”, Jurnal Al-Ta'dib, Vol. 6, No. 2, Juli-Desember.

Wahab, Rochidin. "Pembelajaran Pai dalam Mewarna Pendidikan di Sekolah" dalam Jurnal Kependidikan Vol. 41, Nomor 2, November 2011

http://blog.unnes.ac.id/seputarpendidikan/2015/10/13/komponen-komponen-pendidikan/ https://www.alinea.id/nasional/merdeka-belajar 
https://www.kemdikbud.go.id/main/blog/2019/11/pidato-mendikbud-nadiem-makarim-padaupacara-bendera-peringatan-hari-guru-nasional-2019

https://nasional.kompas.com/read/2020/08/27/16515301/ini-penjelasan-mendikbud-nadiem-soalkonsep-merdeka-belajar.

https://gtk.kemdikbud.go.id/read-news/merdeka-belajar 